\title{
PROSTITUTION AND VENEREAL DISEASE* \\ PROPORTION OF VENEREAL DISEASE ACQUIRED FROM PROSTITUTES IN ASIA: A COMPARISON WITH FRANCE, THE UNITED KINGDOM, AND THE UNITED STATES OF AMERICA
}

BY

\author{
R. R. WILLCOX
}

St. Mary's Hospital, London, and King Edward VII Hospital, Windsor; WHO VD and Treponematosis Consultant

The prevalence of venereal disease in prostitutes has been discussed elsewhere (Willcox, 1960, 1961). It has been shewn that prostitutes are still heavily infected with venereal diseases.

In the present paper data are considered relating to venereal disease in the population at large arising from prostitutes in a number of Asian countries and in France, the United Kingdom, and the United States.

One difficulty in assessing such data is that the definition of a prostitute may vary from country to country. Another is the usual absence of suitable controls. Kinsey, Pomeroy, and Martin (1948) have pointed out that venereal diseases are more frequently acquired by the less educated, who more often resort to prostitutes than do men of higher educational levels. While 74 per cent. of single men in the U.S.A. had had some intercourse with prostitutes by the age of 25 , only 28 per cent. of single men of college level had done so. There is no sufficiently objective study to determine the place of prostitution in the spread of venereal disease, as compared with the spread of such diseases by girls of a lower social level who are not prostitutes. Until the total numbers of each in a population can be related to the male population at risk, and the cases of venereal diseases can be related to the number of exposures, this cannot be done. The present report, which is merely a collection of known data, makes no pretence to be such a study.

Furthermore, venereal diseases are usually far more prevalent amongst troops, immigrants, and visitors than in the indigenous population. These persons rely very largely upon prostitutes. If a given population contains a relatively large number of such persons the proportion of cases of venereal

\footnotetext{
* Prepared for WHO VD Seminar, Tokyo, March, 1958. Paper adapted from material in "The Role of Prostitution in the Spread of Venereal Diseases", UN International Review of Criminal Policy. (Willcox, 1958, 13, 67).
}

disease acquired from prostitutes will also be high.

Situation in Asia

Just before a survey of military venereal disease patients in the Far East was made by Radcliffe (1947), the average annual admission rate for venereal diseases in all the Allied land forces, South East Asia Command, was 140 per 1,000. One unit had an incidence of 1,621 per 1,000 per annum. British and Indian troops were interviewed in Singapore, Rangoon, Saigon, Bangkok, Batavia, and Kuala Lumpur. With Indian troops the prostitute was the main source of infection, although brothels as such were relatively little used. Enforcement of bounds was of little value as many exposures took place in daylight in the afternoon. Prostitutes were responsible for 50 per cent. of infections in British troops. In many areas the principal danger was the girl friend with whom the soldier "walked out" for some weeks before intercourse took place; because she was considered to be safe, no precautions were taken. Many men who would not approach a prostitute would willingly expose themselves with a "girl friend".

\section{Ceylon}

Pereira (1956) stated that, of 1,549 cases of venereal infection (early syphilis, gonorrhoea and soft sore), seen in out-stations in Ceylon in 1955, information was available for 1,106 . In $512(46 \cdot 3$ per cent.) the disease was acquired from prostitutes. In Colombo, on the other hand, 1,325 infections were treated during the same year and information was available for 1,232 of them; in 1,027 (83.4 per cent.), the source of infection was a prostitute. In outstations there were 462 cases of early syphilis, 925 cases of gonorrhoea, and 162 cases of chancroid. In Colombo there were 244 cases of early syphilis, 1,081 cases of gonorrhoea, and the number of cases of chancroid was not stated. In both series, however, 
the proportion of infections acquired from prostitutes was much the same for all three diseases.

These figures and others to be presented lend some support to the dictum of Marcussen (1953) that more stable sexual relations are more conducive to the spread of syphilis than to that of gonorrhoea.

\section{Korea}

Asin (1952) noted the high prevalence of chancroid in Korean prostitutes and reported no less than 1,402 cases in American troops-a community in which all sexual contacts were with prostitutes.

Gudgel (1954) encountered many cases of molluscum contagiosum on the genitalia of American servicemen after intercourse with Korean prostitutes. Some of these men had had further intercourse in the United States before the lesions were noted. Non-gonococcal urethritis was also commonly acquired in Korea (Crouch, Reese, and Boudreau, 1953). Barrett, Silbar, and McGinley (1954) found that, of seventy men with genital warts (condylomata acuminata) seen in a military station in the U.S.A., 65 (92.9 per cent.) admitted previous sexual contact in Japan or Korea, and 24 of their wives were later affected with warts.

\section{Japan}

Some $76 \cdot 2$ per cent. of venereal infection in males in Japan in 1954 arose from prostitutes. Of 51,667 male cases, 39,366 followed intercourse with suspected prostitutes, 299 with friends, 393 with the marital partner, and 3,489 arose from other sources. In 8,120 cases the source was unknown (Huggins, 1956). Prostitutes accounted for no less than $90 \cdot 4$ per cent. of the cases in which the source was known.

That syphilis rates are higher in persons who associate with prostitutes is indicated by the results of mass blood-testing surveys undertaken in Japan during 1954 (Table I).

\section{TABLE I}

RESULTS OF MASS SERUM TESTING FOR SYPHILIS, BY OCCUPATION (EXCLUDING PROSTITUTES), JAPAN, 1954

$$
\text { (Huggins, 1956) }
$$

\begin{tabular}{|c|c|c|c|}
\hline \multirow{2}{*}{ Group } & \multirow{2}{*}{$\begin{array}{c}\text { No. } \\
\text { Examined }\end{array}$} & \multicolumn{2}{|c|}{ Sero-Positive } \\
\hline & & No. & Per cent. \\
\hline 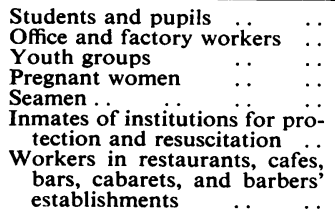 & $\begin{array}{r}48,397 \\
108,913 \\
58,947 \\
397,592 \\
1,034 \\
1,450 \\
199,842\end{array}$ & $\begin{array}{r}515 \\
2,389 \\
693 \\
10,507 \\
76 \\
119\end{array}$ & $\begin{array}{l}1 \cdot 1 \\
2 \cdot 2 \\
1 \cdot 2 \\
2 \cdot 7 \\
7 \cdot 4 \\
8 \cdot 2\end{array}$ \\
\hline
\end{tabular}

The poor personal hygiene of prostitutes and the absence of douching facilities were considered by Graham (1952) to be contributory factors to the high incidence of chancroid encountered in the occupying American forces.

\section{Singapore}

This is an international port, a great city, and the headquarters of the armed forces in the Far East. According to the Census Report of 1947, quoted by Ram (1956), the excess of males over females in the age group 15-44 years in the indigenous population was 67,237 , but counting service personnel, transients, and persons afloat in the port, this excess is more likely of the order of 100,000 . All these factors favour prostitution by the law of supply and demand. It is estimated that on the average a promiscuous woman in Singapore exposes herself four times each day.

Ram (1950) reported that the vast majority of males with venereal disease in Singapore were infected by prostitutes (Table II).

TABLE II

SOURCE OF V.D. INFECTION IN 3,107 MALE CASES IN SOCIAL HYGIENE CLINICS OF SINGAPORE, JANUARY-JUNE, 1950 (Ram, 1950)

\begin{tabular}{|c|c|c|c|c|c|}
\hline \multirow{2}{*}{\multicolumn{3}{|c|}{ Race }} & \multirow{2}{*}{$\begin{array}{c}\text { Total No. } \\
\text { of Cases }\end{array}$} & \multicolumn{2}{|c|}{ Sources of Infection } \\
\hline & & & & Amateurs & Prostitutes \\
\hline $\begin{array}{l}\text { Chinese } \\
\text { Indians } \\
\text { Malays } \\
\text { Eurasians } \\
\text { Europeans } \\
\text { Indonesians } \\
\text { Others... }\end{array}$ & $\begin{array}{l}\ldots \\
\cdots \\
\cdots \\
\cdots \\
\cdots\end{array}$ & $\begin{array}{c}\cdots \\
\cdots \\
\cdots \\
\cdots \\
\cdots\end{array}$ & $\begin{array}{r}1,823 \\
850 \\
171 \\
20 \\
118 \\
75 \\
50\end{array}$ & $\begin{array}{r}47 \\
22 \\
13 \\
1 \\
12 \\
2 \\
1\end{array}$ & $\begin{array}{r}1,776 \\
828 \\
158 \\
19 \\
106 \\
73 \\
49\end{array}$ \\
\hline Total .. & & & $\begin{array}{r}3,107 \\
100\end{array}$ & $\begin{array}{c}98 \\
3 \cdot 2\end{array}$ & $\begin{array}{l}3,009 \\
96 \cdot 8\end{array}$ \\
\hline
\end{tabular}

Of 3,107 infections in all races reported during 6 months in 1950, 96.8 per cent. were acquired from prostitutes, and in 1955 prostitutes were responsible for 5,022 infections (recent and old) out of 5,035 reported, which is very nearly 100 per cent. (Ram, 1956).

\section{Taiwan}

Idsøe (1956) reported that the great majority of patients with venereal disease seen in Taipei had contracted the infection from clandestine prostitutes in the "tea-houses". 


\section{Thailand}

Vuletic (1956) reported that almost all venereal infections in Thailand were contracted from prostitutes. The brothel is universal and men in occupations which lead them to consort with prostitutes have the highest sero-positivity rates. Surveys have shown the sero-positivity rate in samlor drivers to be as high as 70 per cent. and in taxi drivers 60 per cent. (Policemen come next with 40 per cent.).

\section{Situation in France}

Figures obtained from l'Institut National d'Hygiene (Péquignot, 1956) for the years 1945 and 1946 are given in Table III. Brothels ceased to be recognized in France on October 12, 1946, and isolated prostitutes are no longer registered with the police, all responsibility for the medical examination of prostitutes resting with the Health Department. At the time of closure there were 4,840 prostitutes in 827 brothels and a further 9,028 prostitutes were inscribed or registered with the police - a total of 13,868 (U.N.O., 1948).

TABLE III

SOURCE OF ALL VENEREAL DISEASE IN FRANCE, 1945-1946 Institut National d'Hygiene

\begin{tabular}{|c|c|c|c|c|c|}
\hline \multicolumn{4}{|c|}{ Source of Disease } & 1945 & 1946 \\
\hline $\begin{array}{c}\text { Total Cases } \\
\text { Available }\end{array}$ & $\begin{array}{l}\text { for whom } \\
\ldots\end{array}$ & $\begin{array}{c}\text { Information } \\
\ldots\end{array}$ & $\begin{array}{c}\text { was } \\
\cdots\end{array}$ & 22,702 & 22,570 \\
\hline Group .. & \multicolumn{2}{|c|}{$\begin{array}{l}\text { Inscribed prostitutes } \\
\text { Clandestine prostitutes } \\
\text { Marital partners .. } \\
\text { Free relations . . } \\
\text { Non-venereal contacts }\end{array}$} & $\begin{array}{l}\cdots \\
\cdots \\
\cdots \\
\cdots\end{array}$ & $\begin{array}{r}3,392 \\
4,313 \\
1,977 \\
12,921 \\
99\end{array}$ & $\begin{array}{r}1,850 \\
3,772 \\
1,788 \\
14,922 \\
238\end{array}$ \\
\hline \multirow{3}{*}{$\begin{array}{c}\text { Percentage } \\
\text { derived } \\
\text { from } \\
\text { Prostitutes }\end{array}$} & Inscribed & $\cdots$ & . & $14 \cdot 9$ & $8 \cdot 2$ \\
\hline & \multicolumn{2}{|c|}{ Clandestine } & $\cdots$ & $19 \cdot 0$ & $16 \cdot 7$ \\
\hline & Total & . & $\cdots$ & $33 \cdot 9$ & $24 \cdot 9$ \\
\hline \multicolumn{4}{|c|}{ Percentage derived from Free Relations .. } & $56 \cdot 9$ & $66 \cdot 1$ \\
\hline
\end{tabular}

It is evident that, even when the brothels were flourishing, prostitution accounted for only about one-quarter to one-third of the venereal infections in France, and that the majority resulted from free relations. The proportion of cases of venereal disease due to prostitutes has further declined since the closure of the brothels.

(a) Gonorrhoea.-In 1949, of 14,558 cases of gonorrhoea in males, $1,439(9.8$ per cent.) were contracted from prostitutes. In 1952, of 10,071 cases of gonorrhoea in males, $1,142(11 \cdot 3$ per cent.) were derived from this source, and in 1955 prostitutes accounted for 1,053 of 11,003 male infections $(10 \cdot 4$ per cent.). (b) Primary and Secondary Syphilis.-In 1949, of 2,755 cases of primary and secondary syphilis in males, 357 (12.9 per cent.) were contracted from prostitutes, whereas in 1952 prostitutes accounted for 123 of 1,156 male cases (10.6 per cent.), and in 1955 for 95 of 713 male cases $(13 \cdot 2$ per cent).

(c) Soft Sore.-Chancroid is not a very serious public health problem in France, but the few cases that do occur are often derived from prostitutes. In 1949, of 187 male cases, 63 (33.7 per cent.) arose from prostitutes. In 1952, of 102 male infections, 28 ( 27.4 per cent.), and in 1955 , of 99 cases only 14 (14 per cent.) were derived from this source.

The relative damage caused by inscribed and clandestine prostitutes in 1945 and 1946 is shown in Table IV. That the clandestine prostitutes did the greater damage is evident, but their numbers were very much greater.

TABle IV

TYPE OF PROSTITUTE AS SOURCE OF INFECTION IN FRANCE, 1945-46, BY TYPE OF DISEASE Institut National d'Hygiene

\begin{tabular}{|c|c|c|c|c|c|}
\hline \multicolumn{3}{|c|}{ Type of Venereal Disease } & Gonorrhoea & $\begin{array}{l}\text { Primary } \\
\text { and } \\
\text { Secondary } \\
\text { Syphilis }\end{array}$ & $\begin{array}{l}\text { Soft } \\
\text { Sore }\end{array}$ \\
\hline \multicolumn{3}{|c|}{$\begin{array}{l}\text { Total Cases for whom Inform- } \\
\text { ation was Available. . }\end{array}$} & 30,265 & 11,825 & 1,600 \\
\hline \multirow{3}{*}{$\begin{array}{c}\text { Cases } \\
\text { derived } \\
\text { from } \\
\text { Prostitutes }\end{array}$} & Total $\ldots$ & $\cdots$ & 9,273 & 3,109 & 889 \\
\hline & Inscribed & $\cdots$ & 3,906 & 895 & 434 \\
\hline & Clandestine & . & 5,367 & 2,214 & 455 \\
\hline \multicolumn{3}{|c|}{$\begin{array}{l}\text { Percentage of Prostitutional } \\
\text { Cases derived from Inscribed } \\
\text { Prostitutes }\end{array}$} & & & \\
\hline Prostitutes & $\cdots \quad \cdots$ & $\cdots$ & $42 \cdot 1$ & $28 \cdot 8$ & $48 \cdot 8$ \\
\hline
\end{tabular}

Of the gonococcal infections due to prostitutes, $42 \cdot 1$ per cent. arose from inscribed women, as against only 28.8 per cent. of the cases of primary and secondary syphilis.

\section{Situation in the United Kingdom}

In Manchester, Laird $(1956,1957)$ reported that 30 per cent. of gonococcal infections and 38 per cent. of cases of early syphilis in males were contracted from prostitutes.

Considerable information from the whole country concerning gonorrhoea has been made available by the British Cooperative Clinical Group Study (1956). Data collected from numerous clinics relating to 
some 7,157 new cases and 1,026 re-infections treated during 1954 were arranged by area:

(1) Seaports;

(2) Inland industrial cities;

(3) London (3 large clinics chosen);

(4) Smaller, mainly non-industrial, towns and rural areas with little gonorrhoea.

Information regarding occupation was available for 1,023 of the 1,153 female patients, and of these 215 ( $21 \cdot 0$ per cent.) admitted being prostitutes. This proportion is certainly an underestimate, as many prostitutes must have given an occupation which resulted in their being classified in other groups.

Table V shows a greater proportion of the cases of gonorrhoea in females which were treated in London and the sea-ports occurred in prostitutes than in the inland cities and quiet areas, and that in London and the sea-ports prostitutes accounted for a significant percentage of the female reservoir of gonorrhoea.

TABLE V

FEMALE GONORRHOEA CASES, BY OCCUPATION AND AREA, UNITED KINGDOM, 1954 (Brit. Coop, Clin. Group, 1956)

\begin{tabular}{|c|c|c|c|c|c|c|}
\hline Area & . & Ports & $\begin{array}{l}\text { Inland } \\
\text { Cities }\end{array}$ & London & $\begin{array}{l}\text { Quiet } \\
\text { Areas }\end{array}$ & Total \\
\hline \multicolumn{2}{|c|}{$\begin{array}{l}\text { Total Cases } \\
\text { Cases for whom Informa- } \\
\text { tion was Available }\end{array}$} & $\begin{array}{l}446 \\
408\end{array}$ & 199 & 466 & 42 & 1,153 \\
\hline $\begin{array}{l}\text { Occu- } \\
\text { pation }\end{array}$ & $\begin{array}{l}\text { Prostitute } \\
\text { Not prostitute }\end{array}$ & $\begin{array}{r}89 \\
319\end{array}$ & $\begin{array}{r}8 \\
116\end{array}$ & $\begin{array}{l}114 \\
338\end{array}$ & $\begin{array}{r}4 \\
35\end{array}$ & $\begin{array}{l}215 \\
808\end{array}$ \\
\hline \multicolumn{2}{|c|}{ Percentage Prostitutes } & $21 \cdot 8$ & $6 \cdot 5$ & $25 \cdot 2$ & $10 \cdot 3$ & $21 \cdot 0$ \\
\hline
\end{tabular}

Striking differences in the source of infection were noted between the sexes. Of the 1,105 female cases in which the source of infection was stated, contacts with casual acquaintances (including prostitutional relationships) accounted for only 26.3 per cent. Marital exposure accounted for $31 \cdot 5$ per cent., and contacts with friends for the remainder. In the male, on the other hand, casual acquaintances-including prostitutes-were responsible for $77 \cdot 2$ per cent. of the 5,302 cases in which the relationship was stated, prostitutes for 35.7 per cent., and promiscuous amateurs for 41.5 per cent. Friends accounted for 16.4 per cent., marital exposure for only 4 per cent., and homosexual exposure for only 2.5 per cent. In Table VI the data concerning the male cases have been grouped so as to compare the sea-ports, including London, with the inland industrial cities and quiet areas.

In London and the sea-ports, prostitutes and unpaid casual acquaintances were approximately equally responsible for the causation of gonorrhoea.
TABLE VI

SOURCES OF MALE GONORRHOEAL INFECTION, BY AREA UNITED KINGDOM, 1954 (Brit. Coop. Clin. Group, 1956)

\begin{tabular}{|c|c|c|c|c|c|c|}
\hline \multirow{2}{*}{ Area } & \multirow{2}{*}{. } & & \multirow{2}{*}{$\begin{array}{c}\text { Ports } \\
\text { including } \\
\text { London }\end{array}$} & \multirow[b]{2}{*}{$\begin{array}{l}\text { Other } \\
\text { Areas } \\
-\end{array}$} & \multicolumn{2}{|c|}{ Total } \\
\hline & & $\cdots$ & & & No. & $\begin{array}{c}\text { Per } \\
\text { cent. }\end{array}$ \\
\hline \multicolumn{3}{|c|}{$\begin{array}{l}\text { Total Cases } \\
\text { Cases for whom Information was } \\
\text { Availab!e }\end{array}$} & 4,927 & 1,077 & 6,004 & 100 \\
\hline $\begin{array}{c}\text { Source } \\
\text { of } \\
\text { Infection }\end{array}$ & $\begin{array}{l}\text { Prostitutes . } \\
\text { Casual acquaintanc } \\
\text { Friends ... } \\
\text { Marital partners } \\
\text { Homosexuals }\end{array}$ & & $\begin{array}{r}1,794 \\
1,837 \\
744 \\
169 \\
128\end{array}$ & $\begin{array}{r}99 \\
364 \\
124 \\
41 \\
2\end{array}$ & $\begin{array}{r}1,893 \\
2,201 \\
868 \\
210 \\
130\end{array}$ & $\begin{array}{r}35 \cdot 7 \\
41 \cdot 5 \\
16 \cdot 4 \\
4 \cdot 0 \\
2 \cdot 5\end{array}$ \\
\hline \multicolumn{2}{|c|}{ Percentage Prostitutes } & .. & $38 \cdot 4$ & $15 \cdot 7$ & $35 \cdot 7$ & \\
\hline \multicolumn{3}{|c|}{ Percentage Amateur Pick-ups } & $39 \cdot 3$ & $57 \cdot 8$ & $41 \cdot 5$ & \\
\hline
\end{tabular}

In other areas, however, the unpaid casual acquaintance caused more than three times the number of gonococcal infections than the prostitutes.

In the British data as a whole, the homosexual played a very minor role, being responsible for only 2.5 per cent. of the total cases. In London, however, 117 cases $(6 \cdot 1$ per cent. of those in which the source was known) arose from homosexual contacts, and all were recorded in the two West End clinics chosen, none being found at the East End clinics. Outside London there were only thirteen instances in 3,413 known cases $(0.4$ per cent.). Jefferiss (1956), in a study of the homosexual with venereal disease in London, while noting that $8 \cdot 4$ per cent. of 1,000 consecutive patients attending a West End venereal diseases clinic had recently had sexual experience with a male, concluded that homosexual prostitutes were a rarity.

Summarizing the British material, prostitutes comprised at least 21 per cent. of the known female reservoir of gonococcal infection in 1954, more so in the sea-ports and London than in the inland cities and quiet areas. $77 \cdot 2$ per cent. of male infections were contracted as a result of casual relationship. In the sea-ports and in London the prostitute and casual unpaid pick-up were of almost equal importance: in other areas casual unpaid pick-ups were responsible for over three times more gonococcal infections than the prostitutes. The homosexual played no significant part outside London.

Earlier, during World War II, Wittkower and Cowan (1944) undertook a survey of 200 patients with venereal disease in military hospitals. No less than 152 infections (76 per cent.) were obtained from a "pick-up", 55 per cent. of them encountered in a public house and 20 per cent. in the street. Of the "pick-ups", $22 \cdot 5$ per cent. were described as 
married women whose husbands were away. In 18 per cent. the infection arose from a woman friend and in only 6 per cent. from a prostitute (Dicks, 1953).

\section{Situation in the United States of America}

In New York City, Rosenthal and Kerchner (1945) reported the nature of the contact in 7,786 military cases reported by the U.S. Army in 1944. Similarly, Fiumara (1952) gave the nature of contact relationship in 714 servicemen with venereal disease ( 55 with syphilis and the remainder with gonorrhoea) who named Massachusetts as the source of their infections. Approximately 60 per cent. were white and 40 per cent. were Negro: 80 per cent. were single (Table VII).

TABLE VII

RELATION OF CONTACTS TO MILITARY PATIENTS IN U.S.A.

\begin{tabular}{|c|c|c|c|c|c|}
\hline \multirow{2}{*}{ Area } & \multirow{2}{*}{. } & \multicolumn{2}{|c|}{$\begin{array}{l}\text { New York, } 1944 \\
\text { (Rosenthal and } \\
\text { Kerchner, 1948) }\end{array}$} & \multicolumn{2}{|c|}{$\begin{array}{c}\text { Massachusetts, } \\
\text { 1951 } \\
\text { (Fiumara, 1952) }\end{array}$} \\
\hline & & No. & $\begin{array}{c}\text { Per } \\
\text { cent. }\end{array}$ & No. & $\begin{array}{c}\text { Per } \\
\text { cent. }\end{array}$ \\
\hline $\begin{array}{l}\text { Relation- } \\
\text { ship } \\
\text { of } \\
\text { Contact }\end{array}$ & 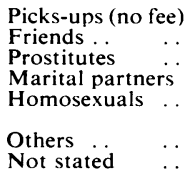 & $\begin{array}{r}5,315 \\
1,461 \\
956 \\
41 \\
\text { Not } \\
\text { stated } \\
13 \\
-\end{array}$ & $\begin{array}{c}68 \cdot 3 \\
18 \cdot 8 \\
12 \cdot 2 \\
0 \cdot 5 \\
\text { Not } \\
\text { stated } \\
0 \cdot 2 \\
-\end{array}$ & $\begin{array}{r}551 \\
144 \\
60 \\
16 \\
1 \\
\\
2 \\
7\end{array}$ & $\begin{array}{r}70 \cdot 6 \\
18 \cdot 4 \\
7 \cdot 7 \\
2 \cdot 0 \\
0 \cdot 1 \\
0 \cdot 3 \\
0 \cdot 9\end{array}$ \\
\hline Total & $\ldots$ & 7,786 & $100 \cdot 0$ & 781 & $100 \cdot 0$ \\
\hline
\end{tabular}

It was noted that the homosexual played no significant role and that many times more contacts were amateurs than were prostitutes. It is not known, however, what proportion of the infected servicemen from the units from which the patients were drawn had had intercourse with prostitutes. In the U.S.A. the May Act of 1946 empowers Federal action to forbid prostitution within areas surrounding military camps and naval stations. Kinsey and others (1948) noted that nearly 10 per cent. of the total sexual outlet of single American males up to the age of 30 is derived from prostitutes and that these provide about one-tenth of the male's total pre-marital intercourse. It is noteworthy that prostitutes account for only $11 \cdot 8$ per cent. of the 8,567 contacts noted in these series.

In a further paper Fiumara (1956) considered the sources of venereal infection in military patients in Massachusetts in 1954 and compared them with those of civilian patients (Table VIII).
TABLE VIII

RELATION OF CONTACTS TO MILITARY AND CIVILIAN PATIENTS, MASSACHUSETTS, 1954 (Fiumara, 1956)

\begin{tabular}{|c|c|c|c|c|c|}
\hline \multirow{2}{*}{ Patients } & \multirow{2}{*}{$\begin{array}{lll}. & \cdots & \cdots\end{array}$} & \multicolumn{2}{|c|}{ Military } & \multicolumn{2}{|c|}{ Civilian } \\
\hline & & No. & $\begin{array}{c}\text { Per } \\
\text { cent. }\end{array}$ & No. & $\begin{array}{c}\text { Per } \\
\text { cent. }\end{array}$ \\
\hline $\begin{array}{l}\text { Relation- } \\
\text { ship } \\
\text { of } \\
\text { Contact }\end{array}$ & $\begin{array}{ll}\text { Pick-ups } & \ldots \\
\text { Friends .. } & \ldots \\
\text { Prostitutes } & \ldots \\
\text { Marital partners } \\
\text { Homosexuals .. }\end{array}$ & $\begin{array}{r}457 \\
137 \\
52 \\
18 \\
1\end{array}$ & $\begin{array}{r}68 \cdot 7 \\
20 \cdot 6 \\
7 \cdot 8 \\
2 \cdot 7 \\
0 \cdot 2\end{array}$ & $\begin{array}{r}495 \\
256 \\
42 \\
104 \\
10\end{array}$ & $\begin{array}{r}54 \cdot 6 \\
28 \cdot 2 \\
4 \cdot 6 \\
11 \cdot 5 \\
1 \cdot 1\end{array}$ \\
\hline Total & . & 665 & $100 \cdot 0$ & 907 & $100 \cdot 0$ \\
\hline
\end{tabular}

The military situation in 1954 as regards sources of venereal disease had not appreciably altered since the previous investigation. The picture for civilians was much the same although the marital partner naturally featured more conspicuously and the percentage of cases due to prostitutes was even lower.

Homosexuality, it is noted, again played a minor role, although some of this is probably concealed. Of 164 males with infectious syphilis seen in a large American city, Vandow (1956) reported that 104 were found to be heterosexuals, 15 bisexuals, and 45 homosexuals. These patients named 665 contacts, of which 290 were female and not less than 375 were male, and of 84 contacts found infected 53 were males. In the writer's experience in London, the really promiscuous homosexual is usually an "amateur" rather than a prostitute.

Of infections caught by U.S. Naval personnel abroad in $1951,87.6$ per cent. of 1,229 cases contracted in Mexico were contracted from prostitutes (Liberti, 1956). In Cuba 96.9 per cent. of 894 cases; in the West Indies $84 \cdot 1$ per cent. of 433 cases; in Panama 83.1 per cent. of 242 cases; in Puerto Rico and the Virgin Islands $65 \cdot 8$ per cent. of 319 cases; and in South America 93.1 per cent. of 29 cases. This, like the military data referring to SouthEast Asia in war time quoted at the beginning of this paper, again illustrates the fact that troops and itinerants are usually infected with venereal disease by prostitutes when away from home.

\section{Discussion}

The figures presented do not indicate the relative moral standards of each country, but only the pattern of sexual behaviour. Obviously, in circumstances in which 100 per cent. of sexual intercourse of a community is with prostitutes, it is to be expected that 100 per cent. of venereal infections may arise from this source. In places where there is 
an abundance of "good-time girls", the prostitute will be given a lower rating although the moral standards in each community may be the same.

Marked differences are noted between Asian countries and Europe and the U.S.A. In Colombo, Ceylon, 83 per cent. of venereal infections are reported as derived from prostitutes (46 per cent. in out stations), in Japan 90 per cent., in Singapore 96-99 per cent., in Thailand "almost all", and Taiwan "the great majority" of infections. In France, on the other hand, only 25 to 34 per cent. of infections were caught from prostitutes, in Great Britain 15-39 per cent., and in the U.S.A. only 5-13 per cent. of infections.

\section{Summary and Conclusions}

(1) The proportion of venereal disease contracted from prostitutes in a number of countries is noted.

(2) Difficulties in the definition of a prostitute make exact comparison difficult and the figures reflect only differences in the patterns of sexual behaviour in the countries concerned.

(3) In a number of Asian countries, 80-90 per cent. or more of venereal infections arise from prostitutes, as compared with 25-34 per cent. in France, 15-19 per cent. in Great Britain, and 5-13 per cent. in the U.S.A.

(4) In areas where prostitutes account for only a small proportion of venereal infections, their activities have been taken over by the "good-time girl", who is, in fact, often morally a prostitute but not generally regarded as such.

(5) Nationals of countries in which only a small proportion of venereal disease is acquired from prostitutes show a very high proportion of venereal infections derived from this source when away from home.

\section{REFERENCES}

Asin, J. (1952). Amer. J. Syph., 36, 483.

Barrett, T. J., Silbar, J. D., and McGinley, J. F. (1954). J. Amer. med. Ass., 154, 333.

British Cooperative Clinical Group (1956). Brit. J. vener. Dis., 32, 21.

Crouch, R. D., Reese, J. E., and Boudreau, H. J. (1953). U.S. armed Forces med. J., 4, 1159.

Dicks, H. V. (1953). "Psychological Aspects of Promiscuity". Lecture at WHO Port Demonstration Centre VD Course, Rotterdam.

Fiumara, N. J. (1952). Amer. J. Syph., 36, 579.

(1956). U.S. armed Forces med. J., 7, 327.
Graham R. S. (1952). Amer. J. Syph., 36, 433.

Gudgel, E. F. (1954). U.S. armed Forces med. J., 5, 1207.

Huggins, D. R. (1956). WHO Unpublished Working Document. V/3/412/2 Japan.

Idsøe, O. (1956). Personal communication.

Jefferiss, F. J. G. (1956). Brit. J. vener. Dis., 32, 17.

Kinsey, A. C., Pomeroy, W. B., and Martin, C. E. (1948). "Sexual Behaviour in the Human Male", p. 608. Saunders, Philadelphia.

Laird, S. M. (1956). Brit. J. vener. Dis., 32, 181. (1957). Ibid., 33, 242.

Liberti, D. V. (1956). Personal communication.

Marcussen, P. V. (1953). Amer. J. syph., 37, 355.

Péquignot, C. (1956). Personal communication.

Pereira, E. D. C. (1956). Personal communication.

Radcliffe, T. A. (1947). J. roy. Army med. Cps, 89, 122.

Ram, L. M. (1950). Proc. Alumni. Ass. King Edward VII Coll. Med. Singapore, 3, 285.

(1956). Personal communication.

Rosenthal, T., and Kerchner, G. (1948). Amer. J. Syph., 32, 256.

United Nations Organization (1948). "Traffic in Women and Children. Summary of Annual Reports for 1946-47'. Lake Success, New York.

Vandow, J. E. (1956). Personal communication.

Vuletic, A. (1956). Personal communication.

Willcox, R. R. (1957). "The Role of Prostitution in the Spread of Venereal Diseases". WHO Working Document INT/VDT/89. International Review of Criminal Policy (1958), 13, 67. (1960). Med. Press, 244, 521.

(1961). Brit. J. prev. soc. Med., 15, 42.

Wittkower, E. D., and Cowan, J. (1944). Psychosomat. Med., 6, 287.

La prostitution et les maladies vénériennes.

Proportion des cas des maladies vénériennes due aux prostituées en Asie. Comparaison avec la France, le Royaume-Uni, et les Etats-Unis.

\section{RÉSUMÉ}

(1) On note la proportion des infections vénériennes due aux prostituées dans certains pays.

(2) La difficulté de la définition précise du terme "prostituée" nous empêche de faire une comparaison exacte, et les résultats de cette enquête montrent seulement les différences de conduite sexuelle dans les pays étudiés.

(3) Dans certains régions de l'Asie, 80 ou $90 \%$ des infections vénériennes sont dues aux prostituées, auprès de 25 à $34 \%$ en France, 15 à $19 \%$ en GrandeBretagne, et 5 à $15 \%$ aux États-Unis.

(4) Dans les régions où les prostituées sont responsables pour peu d'infections, leur rôle a été pris par les clandestines, qui sont en effet des prostituées en tout sauf le nom.

(5) Les citoyens des pays où peu d'infections sont acquises auprès des prostituées sont très souvent atteints de cette source quand ils voyagent à l'étranger. 